\title{
Front Matter: Volume 10431
}

, "Front Matter: Volume 10431," Proc. SPIE 10431, Remote Sensing Technologies and Applications in Urban Environments II, 1043101 (7 November 2017); doi: 10.1117/12.2303928

SPIE. Event: SPIE Remote Sensing, 2017, Warsaw, Poland 


\title{
Remote Sensing Technologies and Applications in Urban Environments II
}

\author{
Thilo Erbertseder \\ Nektarios Chrysoulakis \\ Ying Zhang \\ Editors
}

11-13 September 2017

Warsaw, Poland

Sponsored and Published by

SPIE

Cooperating Organisations

Innovation Centre for Sensor and Imaging Systems (United Kingdom)

ADS Scotland (United Kingdom)

The Knowledge Transfer Network (United Kingdom)

Visit Scotland (United Kingdom)

European Regional Development Fund (Belgium)

Technology Scotland (United Kingdom)

European Association of Remote Sensing Companies (Belgium)

European Association of Remote Sensing Laboratories (Germany)

The British Association of Remote Sensing Companies (United Kingdom)

Remote Sensing \& Photogrammetry Society (United Kingdom)

Volume 10431 
The papers in this volume were part of the technical conference cited on the cover and title page. Papers were selected and subject to review by the editors and conference program committee. Some conference presentations may not be available for publication. Additional papers and presentation recordings may be available online in the SPIE Digital Library at SPIEDigitalLibrary.org.

The papers reflect the work and thoughts of the authors and are published herein as submitted. The publisher is not responsible for the validity of the information or for any outcomes resulting from reliance thereon.

Please use the following format to cite material from these proceedings:

Author(s), "Title of Paper," in Remote Sensing Technologies and Applications in Urban Environments II, edited by Thilo Erbertseder, Nektarios Chrysoulakis, Ying Zhang, Wieke Heldens, Proceedings of SPIE Vol. 10431 (SPIE, Bellingham, WA, 2017) Seven-digit Article CID Number.

ISSN: 0277-786X

ISSN: 1996-756X (electronic)

ISBN: 9781510613263

ISBN: 9781510613270 (electronic)

Published by

SPIE

P.O. Box 10, Bellingham, Washington 98227-0010 USA

Telephone +1 3606763290 (Pacific Time) · Fax +1 3606471445

SPIE.org

Copyright (c) 2017, Society of Photo-Optical Instrumentation Engineers.

Copying of material in this book for internal or personal use, or for the internal or personal use of specific clients, beyond the fair use provisions granted by the U.S. Copyright Law is authorized by SPIE subject to payment of copying fees. The Transactional Reporting Service base fee for this volume is $\$ 18.00$ per article (or portion thereof), which should be paid directly to the Copyright Clearance Center (CCC), 222 Rosewood Drive, Danvers, MA 01923. Payment may also be made electronically through CCC Online at copyright.com. Other copying for republication, resale, advertising or promotion, or any form of systematic or multiple reproduction of any material in this book is prohibited except with permission in writing from the publisher. The CCC fee code is 0277 $786 \mathrm{X} / 17 / \$ 18.00$.

Printed in the United States of America.

Publication of record for individual papers is online in the SPIE Digital Library.

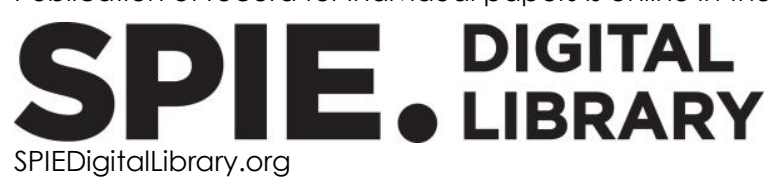

Paper Numbering: Proceedings of SPIE follow an e-First publication model. A unique citation identifier (CID) number is assigned to each article at the time of publication. Utilization of CIDs allows articles to be fully citable as soon as they are published online, and connects the same identifier to all online and print versions of the publication. SPIE uses a seven-digit CID article numbering system structured as follows:

- The first five digits correspond to the SPIE volume number.

- The last two digits indicate publication order within the volume using a Base 36 numbering system employing both numerals and letters. These two-number sets start with $00,01,02,03$, 04, 05, 06, 07, 08, 09, OA, OB ... 0Z, followed by 10-1Z, 20-2Z, etc. The CID Number appears on each page of the manuscript. 


\title{
Contents
}

\author{
$\checkmark$ Authors \\ vii Conference Committee
}

SESSION $1 \quad$ URBAN AIR QUALITY AND CLIMATE I

1043103 The impact of urban morphology and land cover on the sensible heat flux retrieved by simultaneous satellite and in-situ observations [10431-2]

1043105 Social vulnerability to heat in Greater Atlanta, USA: spatial pattern of heat, NDVI, socioeconomics and household composition [10431-4]

\section{SESSION 2 URBAN AIR QUALITY AND CLIMATE II}

1043106 Mapping urban porosity and roughness characteristics as a mean of defining urban ventilation corridors (Best Student Paper) [10431-5]

1043109 Seasonal variability of aerosols and their characteristics in urban and rural locations of Delhi-NCR [10431-13]

\section{SESSION $3 \quad$ URBAN MONITORING AND PLANNING I}

$10431 \mathrm{OB} \quad$ Use of multi-temporal lidar data to extract changes due to the 2016 Kumamoto earthquake [10431-15]

10431 OC Multi-temporal synthetic aperture radar for bridges monitoring [10431-16]

\section{SESSION $4 \quad$ URBAN MONITORING AND PLANNING II}

10431 OE Defining urban and rural areas: a new approach [10431-18]

10431 OF Predicting urban expansion in Moscow based on night lights [10431-19]

$104310 G \quad$ A local segmentation parameter optimization approach for mapping heterogeneous urban environments using VHR imagery [10431-20]

SESSION $5 \quad$ URBAN MONITORING AND PLANNING III

10431 Ol Optimizing classification performance in an object-based very-high-resolution land useland cover urban application [10431-22] 
10431 0J Building change defection via a combination of CNNs using only RGB aerial imageries [10431-23]

$10431 \mathrm{OL} \quad$ Using remote sensing and GIS in addressing the future decisions regarding underused urban spaces; Hajj sites in Mecca as case study [10431-24]

10431 OM Implication of relationship between natural impacts and land use/land cover (LULC) changes of urban area in Mongolia [10431-26]

10431 ON Exploiting Earth observation data pools for urban analysis: the TEP URBAN project [10431-39]

SESSION 6 SMART CITIES

104300 Towards a rational use of loading and unloading areas in urban environments [10431-27]

10431 OP Valorisation of urban elements through 3D models generated from image matching point clouds and augmented reality visualization based in mobile platforms [10431-28]

$104310 Q \quad$ On-field mounting position estimation of a lidar sensor [10431-29]

10431 OR Application of HyMap image in the environmental survey in Shenzhen, China [10431-30]

POSTER SESSION

10431 OU State estimation with incomplete nonlinear constraint [10431-31]

10431 OV City landscape changes effects on land surface temperature in Bucharest metropolitan area [10431-32]

10431 OW Urban green land cover changes and their relation to climatic variables in an anthropogenically impacted area [10431-33]

10431 OX Metal-coated optical fibers for high temperature sensing applications [10431-34]

10431 OY Monitoring and localization hydrocarbon and sulfur oxides emissions by SRS-lidar [10431-35]

$104310 Z$ Speed scanning system based on solid-state microchip laser for architectural planning [10431-36]

1043110 Spatio-temporal variability of urban heat islands in local climate zones of Delhi-NCR [10431-37] 


\section{Authors}

Numbers in the index correspond to the last two digits of the seven-digit citation identifier (CID) article numbering system used in Proceedings of SPIE. The first five digits reflect the volume number. Base 36 numbering is employed for the last two digits and indicates the order of articles within the volume. Numbers start with 00, 01, 02, 03, 04, 05, 06, 07, 08, 09, OA, OB...0Z, followed by 10-1Z, 20-2Z, etc.

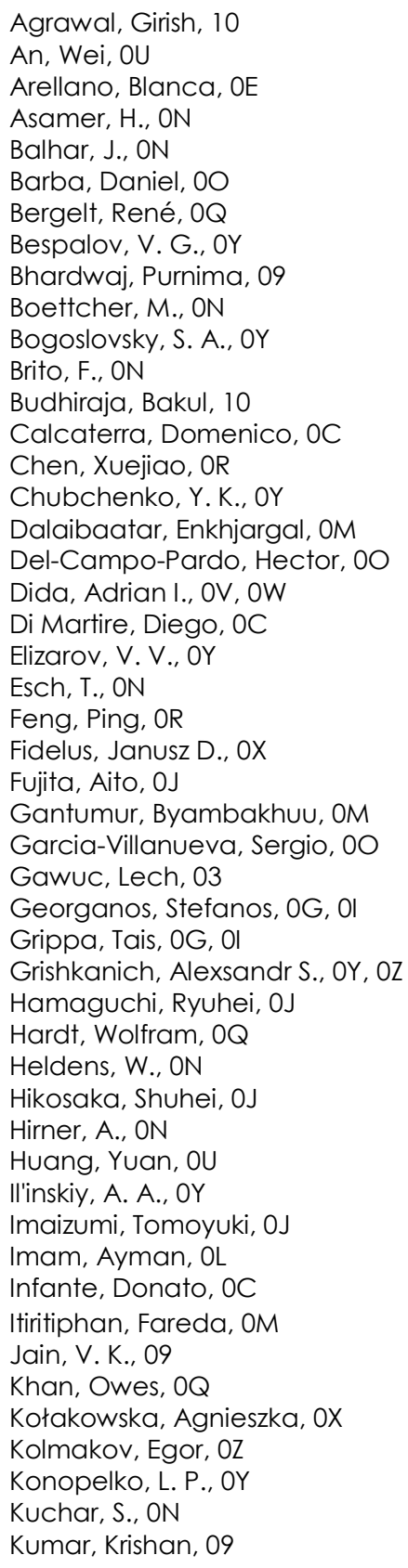

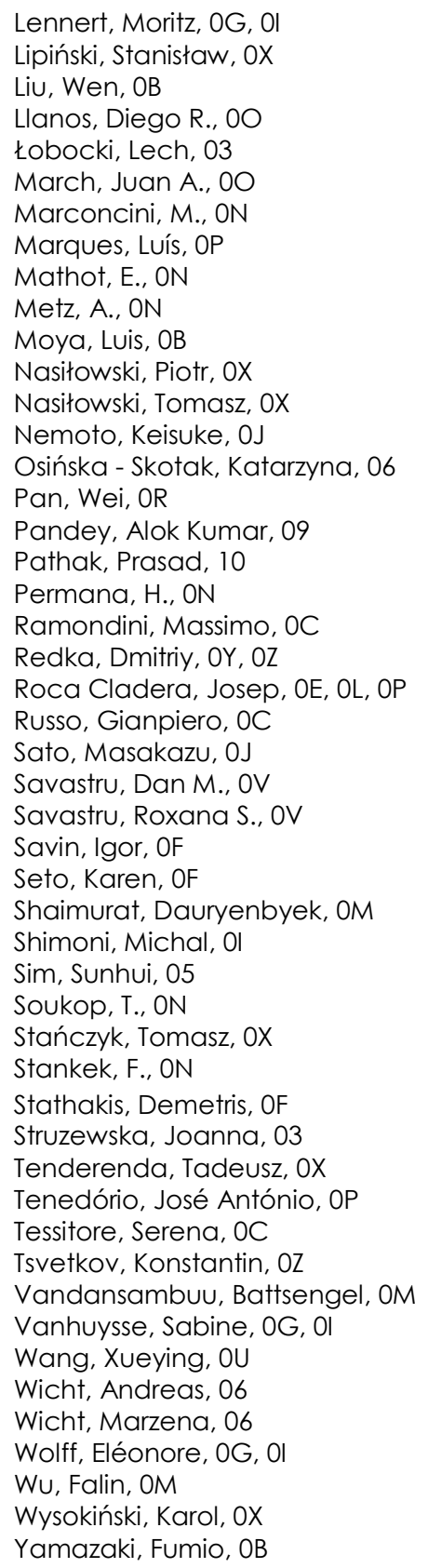


Yang, Xiaomao, OR

Zeidler, J., ON

Zhao, Yan, OM

Zhevlakov, A. P., OY

Zoran, Maria A., OV, OW

Proc. of SPIE Vol. 10431 1043101-6

Downloaded From: https://www.spiedigitallibrary.org/conference-proceedings-of-spie on 26 Apr 2023 Terms of Use: https://www.spiedigitallibrary.org/terms-of-use 


\section{Conference Committee}

Symposium Chair

Klaus Schäfer, (Retired) Karlsruhe Institute of Technology, Institute of Meteorology and Climate Research (Germany)

Symposium Co-chair

Christopher M. U. Neale, University of Nebraska-Lincoln

(United States), Daugherty Water for Food Institute (United States)

Conference Chairs

Thilo Erbertseder, Deutsches Zentrum für Luft- und Raumfahrt e.V.

(Germany)

Nektarios Chrysoulakis, Foundation for Research and TechnologyHellas (Greece)

Ying Zhang, Natural Resources Canada (Canada)

Conference Program Committee

Matthias Budde, Karlsruhe Institute of Technology (Germany)

Thomas Esch, Deutsches Zentrum für Luft- und Raumfahrt e.V. (Germany)

Christopher Small, The Earth Institute (United States)

Carlos Tavares Calafate, Universitat Politécnica de Valencia (Spain)

\section{Session Chairs}

1 Urban Air Quality and Climate I

Wieke Heldens, Deutsches Zentrum für Luft- und Raumfahrt e.V. (Germany)

2 Urban Air Quality and Climate II

Nektarios Chrysoulakis, Foundation for Research and TechnologyHellas (Greece)

3 Urban Monitoring and Planning I

Nektarios Chrysoulakis, Foundation for Research and TechnologyHellas (Greece)

4 Urban Monitoring and Planning II

Wieke Heldens, Deutsches Zentrum für Luft- und Raumfahrt e.V. (Germany) 
5 Urban Monitoring and Planning III

Nektarios Chrysoulakis, Foundation for Research and TechnologyHellas (Greece)

6 Smart Cities

Wieke Heldens, Deutsches Zentrum für Luft- und Raumfahrt e.V. (Germany) 